\title{
Effects of a Novel Convection Heated Roasting Method on Aroma and Umami Taste Components of Vegetable- and Meat-Based Extracts
}

\author{
In-Seek Jeong $(\mathbb{D}$, Geon-Woo Park, Young-Sang Kim, Kyung-Ho Park, Hark Hwangbo, \\ Sang-Yun Lee, and Sang-gu Kim $(\mathbb{D}$ \\ Corporate Technology Office, Pulmuone Co Ltd, 29 Osongsaengmyeong 10-ro Osong-eup Heungdeok-gu, Cheongju 28220, \\ Republic of Korea \\ Correspondence should be addressed to Sang-gu Kim; sgkimn@pulmuone.com
}

Received 9 December 2021; Revised 28 January 2022; Accepted 31 January 2022; Published 25 February 2022

Academic Editor: Fabio Napolitano

Copyright ( 2022 In-Seek Jeong et al. This is an open access article distributed under the Creative Commons Attribution License, which permits unrestricted use, distribution, and reproduction in any medium, provided the original work is properly cited.

\begin{abstract}
Roasting has been widely used in manufacturing food products, ensuring microbial safety, and improving extraction efficiency. Roasting treatment affects various qualities such as the chemical composition, physical properties, colour, aroma, and texture of food. This study determined the effect of novel convection heated roasting on aroma and taste components, that is, amino acids (AAs) and nucleotides in vegetables, meat, and their products. Heat treatment conditions were confirmed with a temperature condition of $250^{\circ} \mathrm{C}$ for $20-50 \mathrm{~min}$ for each raw material. The individual raw materials were each subjected to a convection oven process, then mixed together, and pressurised by heating at $121^{\circ} \mathrm{C}$ for 3 hours to prepare a key-based broth for use in Korean soup dishes. As for aroma components, aroma of fermented spirits, unpleasant aroma, and bad aroma were observed in the absence of roasting. By contrast, convection heated roasting-related aroma components such as savoury fatty aroma, coffee aroma, and roasted barley aroma were observed in the finished products after roasting. The products' sensory profile presumably changed from negative to positive owing to roasting. By roasting, in the case of raw material extracts, the total AA and glutamic acid contents increased to $24.1-38.1 \%$, and for the finished product, the total AA and glutamic acid contents slightly increased to $5.8-8.9 \%$. However, no significant effect of roasting was found on nucleotides. In conclusion, it was concluded that the positive aroma component as well as the total amount of AA (umami taste) increased owing to roasting. The present results contribute immensely to the food industry as the enhancement of taste and aroma can help with the production of more palatable foods as desired by food consumers, thereby increasing the sales of nutritious foods that otherwise consumers may not buy.
\end{abstract}

\section{Introduction}

Two criteria for determining the consumption of nutritious foods are taste and aroma. For food consumers, the taste and aroma of food are crucial factors in selecting the food; therefore, the food industry is constantly making efforts to maintain or improve the unique taste and aroma of food in an optimal state [1]. During food processing, various flavour components including the ones that arouse appetite and sometimes those that cause unpleasant taste or off-flavour are generated [2]. In food, proteins, carbohydrates, and lipids are the main components lending it taste and aroma.
Heat treatment leads to the interaction of these components, and the effects of the processing methods on the components create the taste and aroma that are felt by our sensory organs [3].

Taste ingredients are divided into five main categories: sweet, bitter, salty, sour, and umami; umami is the fifth taste also known as savoury. Umami is a characteristic taste that is imparted by glutamate (glutamic acid) and $5^{\prime}$-ribonucleotides (or nucleotides) such as guanosine monophosphate (GMP) and inosine monophosphate (IMP). This study focused on umami because it is the main taste for developing the basic ingredients of seasonings and soups in processed foods. 
Glutamic acid and nucleotides are present in many foods and play important roles in the taste, palatability, and acceptability of foods. This distinctive taste was first discovered by K. Ikeda, who in 1908 isolated glutamate as the source of taste in a broth used in Japan prepared from seaweed konbu, a substance with high levels of natural glutamate. Monosodium glutamate was first commercially produced in Japan in 1909 and used as a seasoning similar to salt and sugar [4, 5]. In 1913, Ikeda's disciple Kodama examined the constituents of dried skipjack and reported that IMP also had umami taste characteristics [6]. Many years later, during a study of ribonucleotide production through biochemical degradation of yeast RNA, Kuninaka and his colleagues identified GMP as another important umami substance [7-9]. Currently, monosodium glutamate and $5^{\prime}$-ribonucleotides are commercially available as flavouring substances worldwide.

Glutamate, a component of protein, is the most abundant amino acid (AA) in nature. It is found in fish, meat, milk, and several vegetables. It is a dominant umami compound and essential for human metabolism. The nucleotide, IMP, is found in fish, pork, and beef, whereas GMP is present in meats and abundant in mushrooms. Nucleotides are also natural compounds that form the basic components of our body and are vital to human metabolism $[10,11]$.

Aromas in foods and raw materials develop from the interactions of nonvolatile precursors, including free AA, peptides, reducing sugars, vitamins, nucleotides, and unsaturated fatty acids, during cooking. These interactions include the Maillard reaction between an amino compound and a carbonyl compound, oxidation of lipids, thermal degradation of thiamine, and interactions among these pathways [12]. Roasting has been widely used to manufacture traditional tea and is a time- and cost-effective process that ensures microbial safety and improves extraction efficiency [13]. Roasting treatment reportedly affects various qualities such as the chemical composition, physical properties, colour, aroma, and texture of food [14]. This heat treatment processing technology has been used to extend the shelf life of food and improve the content of bioactive substances [15]. When raw materials are roasted, various components change, including an increase in water-soluble solid content, which occurs owing to reactions such as decomposition, synthesis, and condensation [16].

Roasting is a dry-heat cooking method where food is cooked at a high temperature of over $150^{\circ} \mathrm{C}$ for a short or long period. The Maillard reaction and caramelisation cause browning and formation of flavour components giving the surface a crispy texture. When vegetables such as garlic, onion, asparagus, broccoli, and root vegetables are roasted, the sugar components in the vegetables are heated to concentrate the inherent sweetness and original flavour of the vegetables, and the moisture is quickly evaporated without severe browning to maximise the flavour. Large chunks of meat, such as beef, pork, and chicken, are roasted slowly and evenly in the range of $121-375^{\circ} \mathrm{C}$, then cut into small pieces, and heated at $200^{\circ} \mathrm{C}$ or higher; as they tend to dry out excessively, the final step is a short roast after pan cooking $[17,18]$.

Samples used in this study were roasted by convection heating. Heat transfer by convection is slower than radiated heating but faster than conduction heating and is primarily applied to low-viscosity liquid food because it is affected by convection depending on the viscosity of the liquid $[19,20]$. This recipe is a type of dry-heat cooking, where food is cooked quickly with high heat to reduce nutrient loss, improve original taste and flavour, and create a characteristic roasting flavour [21].

A representative raw material for roasting is coffee beans; it is known that the variety and roasting conditions of the beans through the roasting and extraction process affect the flavour of the final coffee drink [22-25]. Research performed on coffee revealed that the processing of raw coffee materials under appropriate roasting conditions can be used to improve the quality of the raw material itself. Other investigators reported that the brownness of barley during roasting was a good indicator of the flavour produced, and roasting time and temperature had a great effect on the colour and yield of barley tea $[26,27]$. In addition to coffee and barley, roasting studies have been conducted on malt [28], sesame [29], mung beans [30], silkworms [31], peel [32], omija [33], and mushrooms [34-36]. These studies reported that the quality of the raw material itself can be increased through various roasting techniques.

A review of the above findings shows that research on roasting commonly involves indulgence foods such as coffee, tea, and vegetable materials. There have been few studies on taste (particularly umami) and aroma-active compounds for basic agricultural or livestock materials related to roasting. The food market has recently been expanding the availability of various seasoning foods, such as sauces and spices, that add flavour and provide food preference. There is a study on the effect of cooking methods with various heating apparatus on beef, pork, and chicken, which included the physical and sensory evaluation of heating loss, shearing force, and meat colour [37-39]. However, chemical evaluation methods have not been conducted.

In this study, we compared the changes in volatile components via gas chromatography-mass spectrometry (GC-MS) and determined the AA and nucleotide contents using a high-performance liquid chromatography-ultraviolet detector (HPLC-UVD) of vegetables, meat, and their mixed products according to the novel convection heated roasting method.

\section{Materials and Methods}

2.1. Sample Preparation by Convection Heated Roasting Method. According to moisture and properties of vegetables and meat, heat treatment conditions were confirmed in a previous study. In the case of vegetables with a temperature condition of $250^{\circ} \mathrm{C}$ when heated for $20 \mathrm{~min}$, the characteristic flavours of garlic, onion, and green onion were most superior. When heated for 10 minutes, a raw smell appeared, and when heated for 30 minutes, a burnt smell appeared. In the case of meat, it was confirmed that the rich roasted flavour of beef, pork, and chicken was well-expressed when heated for $50 \mathrm{~min}$. When heated for 40 minutes, the roasted smell was weak, and when heated for 60 minutes, a burnt smell appeared. The above temperature conditions were applied when manufacturing all raw materials and for finished sauce products. 
For the test of raw materials, three types of agricultural products (onion, garlic, and green onion) and six types of livestock products (beef bone, pork bone, beef brisket, beef tendon, chicken feet, and chicken breast) were prepared by cutting and thawing. Each sample of $3-4 \mathrm{~cm}$ in size and 5-50 g in weight was subjected to a convection heated roasting or nonroasting condition. Of the raw materials, only garlic was roasted without cutting. After heating, they were mixed with purified water at a $1: 10$ ratio and the mixed solution was filtered and used for each instrument analysis.

To test the sauce product, the selected materials among the above ingredients and spice ingredients were mixed and used in the preparation of the key-based broth. The selected materials were beef, pork, chicken, garlic, onion, green onion, ginger, and whole pepper. Each sample was prepared by cutting and thawing of 3-4 cm in size and 5-50 g in weight, under the same condition as in the raw material experiment. The only exception was garlic, which was roasted whole. The individual raw materials were each subjected to a convection oven process, then mixed together, and pressurised by heating at $121^{\circ} \mathrm{C}$ for 3 hours to prepare a key-based broth. The seasoning ingredients used in the finished product were pork bone extract (pork, pork bone enzyme decomposition), chicken, shiitake extract, and yeast extract. Seasonings were prepared by mixing these with the keybased broth followed by heat extraction. The samples were subjected to cooling and fat separation, and the extracted broths were filtered through 100-mesh strainer. Process and sample changes by roasting are shown in Figure 1.

2.2. Reagents and Materials. GC-MS was used to analyse volatile components of the extract, and solid-phase microextraction (SPME) was used for the adsorption of aroma components. The injector liner was an SPME exclusive liner (2637505, Supelco, St. Louis, MO, USA), and the SPME fibre was an assembly polydimethylsiloxane/ divinylbenzene (PDMS/DVB) fibre (Supelco, 57346U) that could absorb water-soluble and oil-soluble volatile substances universally.

AA standards were prepared using the Agilent AA analysis method for AA standards (5061-3330; Agilent Technologies, Santa Clara, CA, USA), and derivatisation reagents are as follows: ortho-phthalaldehyde for primary AA (Agilent, 5061-3335) and 9-fluorenylmethyl chloroformate for secondary AA (Agilent, 5061-3337). The AA standard is composed of the 20 natural AA and manufactured to a concentration of $1 \mathrm{nmol} /$ $\mu \mathrm{L}$. It was diluted two-fold and four-fold to prepare the standard working solutions. The following nucleotide standards were purchased from Sigma-Aldrich (St. Louis, MO, USA) for use as reference standards: inosine $5^{\prime}$-monophosphate disodium salt hydrate (IMP; 57510) and guanosine $5^{\prime}$-monophosphate disodium salt hydrate (GMP; G8377). Stock solutions of $100 \mathrm{mg} / \mathrm{L} \mathrm{IMP}$ and GMP were prepared by dissolving standards in distilled water and diluting to the required concentrations of $1,5,10,25$, and $50 \mathrm{mg} / \mathrm{L}$ to prepare standard working solutions.

The mobile-phase solvents methanol and acetonitrile were of American Chemical Society grade and purchased from Honeywell (Charlotte, NC, USA). Reagent-grade perchloric acid, potassium dihydrogen phosphate $\left(\mathrm{KH}_{2} \mathrm{PO}_{4}\right)$, and sodium dihydrogen phosphate $\left(\mathrm{NaH}_{2} \mathrm{PO}_{4}\right)$ were purchased from Sigma-Aldrich. Sodium hydroxide and potassium hydroxide were purchased from Junsei Chemical Co. (Tokyo, Japan). The distilled water had a resistivity of $18.2 \mathrm{M} \Omega$.

2.3. Instrumental Conditions. GC-MS analysis was performed to screen the aroma components using an Agilent 7890 GC and Agilent 5975C TAD Series GC/MSD System and Agilent GC Sampler 80 G6501 B CTC PAL Gas Autosampler (Agilent Technologies). The method was developed for the analysis of volatile components of the extract as follows: the sample was transferred to a headspace vial, heated, and shaken at $500 \mathrm{rpm}$ for $10 \mathrm{~min}$ at $50^{\circ} \mathrm{C}$ for headspace equilibration. A $24 \mathrm{Ga}, 65 \mu \mathrm{m}$ PDMS/DVB SPME fibre (Supelco) was then inserted into the headspace, and volatile adsorption was performed. The extraction time and temperature were set to $30 \mathrm{~min}$ and $50^{\circ} \mathrm{C}$, respectively. Once the volatiles were extracted, they were desorbed at $250^{\circ} \mathrm{C}$ for $1 \mathrm{~min}$. After each injection, the SPME fibre was heated to $300^{\circ} \mathrm{C}$ under helium flow for $10 \mathrm{~min}$. The liner used was an Inlet Liner, Direct SPME Type procured from Supelco. The splitless injection method was used; the GC column used was DB-WAX $60 \mathrm{~m} \times 0.25 \mathrm{~mm} \times 0.25 \mu \mathrm{m}$ procured from Agilent. The DB-WAX capillary column was used under the following conditions: the oven temperature was initially set at $40^{\circ} \mathrm{C}$ for $5 \mathrm{~min}$, then increased to $60^{\circ} \mathrm{C}$ at a rate of $1^{\circ} \mathrm{C} / \mathrm{min}$, and maintained for $5 \mathrm{~min}$. The temperature was then increased to $120^{\circ} \mathrm{C}$ at $10^{\circ} \mathrm{C} / \mathrm{min}$ and maintained for $10 \mathrm{~min}$. To avoid condensation, the interface temperature was set to $250^{\circ} \mathrm{C}$. In the early development steps, an ionisation voltage of $70 \mathrm{eV}$ and a mass range from 33 to $500 \mathrm{~m} / z$ for total ion chromatogram tracing were used. Volatile compounds were identified using the NIST10 spectral database, and linear retention indices were compared with those of the corresponding pure chemicals.

A 1290 HPLC system (Agilent Technologies with a diode array detector (DAD)) was used for AA and nucleotide analyses. AAs were analysed according to Agilent's application note method [40], and nucleotides were determined in raw materials and sauces by applying the Association of Official Analytical Collaboration official method 2011.20 [41]. The optimised GC-MS and HPLC-DAD settings are listed in Table 1 . The uncertainty provided with each value is an expanded uncertainty about the mean to cover the measurand with approximately $95 \%$ confidence $(p<0.05)$.

\section{Results and Discussion}

3.1. Effect of Convection Heated Roasting on Raw Materials. To confirm flavour characteristics of raw material extracts using convection heated roasting, the changes in aroma and flavour component contents before and after roasting were compared and analysed. Samples were extracted and compared using the following two methods: (1) control-raw materials and (2) roasting-grilling materials using a convection oven process. Each sample was extracted with hot water at $98^{\circ} \mathrm{C}$ for $20 \mathrm{~min}$ for instrumental analysis. For the 

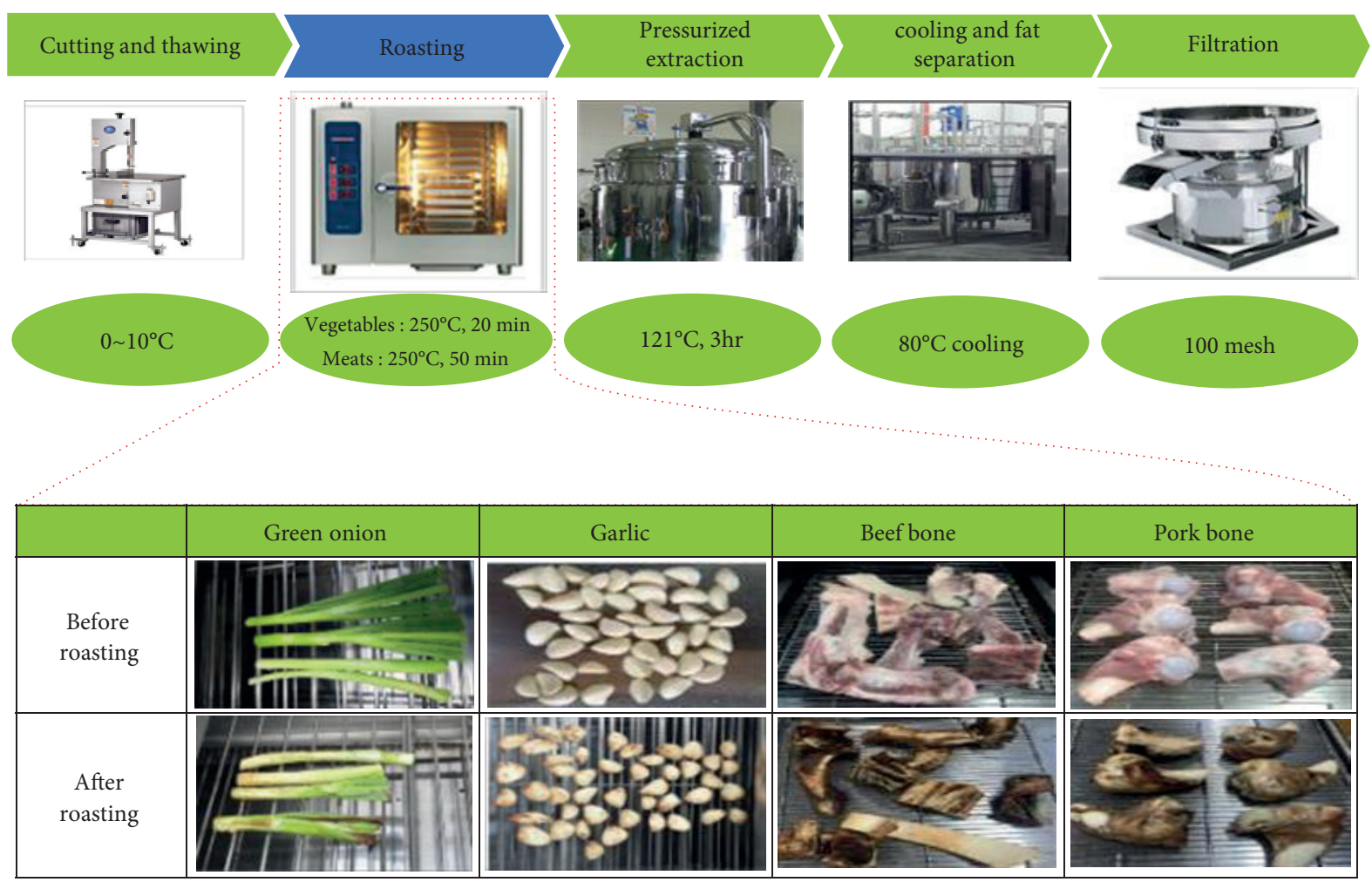

FIGURE 1: Process and change in raw materials by convection heated roasting.

aroma analysis, the MS spectrum of the result peak was matched with the Wiley registry 9th Edition GC/MS Library and Nist 08 Library Spectra DB to derive results.

\subsubsection{Composition of Fragrance Components in Raw Mate-} rials Determined by GC-MS with SPME. Samples were green onion, shrimp, beef bone, garlic, clam, and chicken extract, and the aroma component increased during roasting extraction for all samples except the roasted chicken extract. Alcoholic compounds (such as hexanol and heptanol), alkane-based hydrocarbons (such as octane and decane), and aldehyde groups (such as nonanal and hexanal) were key ingredients of roasting in raw materials. When viewed individually, sulphidebased compounds (e.g., methyl sulphide and methyl allyl disulphide) were identified in green onion and garlic extracts. In addition, differences from the control were confirmed, such as fruit flavour, nut flavour, and components characteristically emitted from heated raw materials detected only in the convection oven and superheated steam. It was confirmed that the convection heated roasting method applying heat directly or indirectly affected the flavour of the extract.

To develop a key base for sauce and soup dishes, SPME analysis was completed on 11 extracts, including green onion and three roasted extracts prepared using five raw materials, including beef bone, and the components detected in the results were organised and exported to databases. A total of 638 ingredients were summarised, among which a few representative ones are presented in Table 2 with the ingredient name, CAS No., detection status, and peak area of each extract.

3.1.2. Analysis of Changes in Umami Components in Raw Materials by Convection Heated Roasting. Representative ingredients of umami can be divided into AA and nucleic acids. AAs are widely distributed in animals and plants, whereas nucleic acids are known to be distributed in fish, meat, and some fungi (dried shiitake, matsutake mushrooms) [10, 11]. Three types of umami ingredients are shown in Figure 2.

After roasting, the AA content of the three agricultural products increased from a minimum of $118 \%$ to a maximum of $509 \%$, and it was confirmed that the total AA increase rate was approximately doubled. The AA content of the six types of livestock products increased from a minimum of $100 \%$ to a maximum of $141 \%$ based on the total AA content. It was estimated that the overall flavour of the raw materials could be efficiently extracted from agricultural products, and the extraction efficiency of livestock products was rated relatively low. The AA composition data are shown in Table 3.

Analysis was not performed in agricultural products because no nucleic acid-based substances are present in them except mushrooms [11]. Analysis in mushrooms has been performed in previous studies; however, mushrooms were excluded from this study because the sensory quality deteriorated owing to the high temperature of the convection oven. Although mushrooms were not evaluated in this 
TABLE 1: Operating conditions for detection of the aroma and umami taste components.

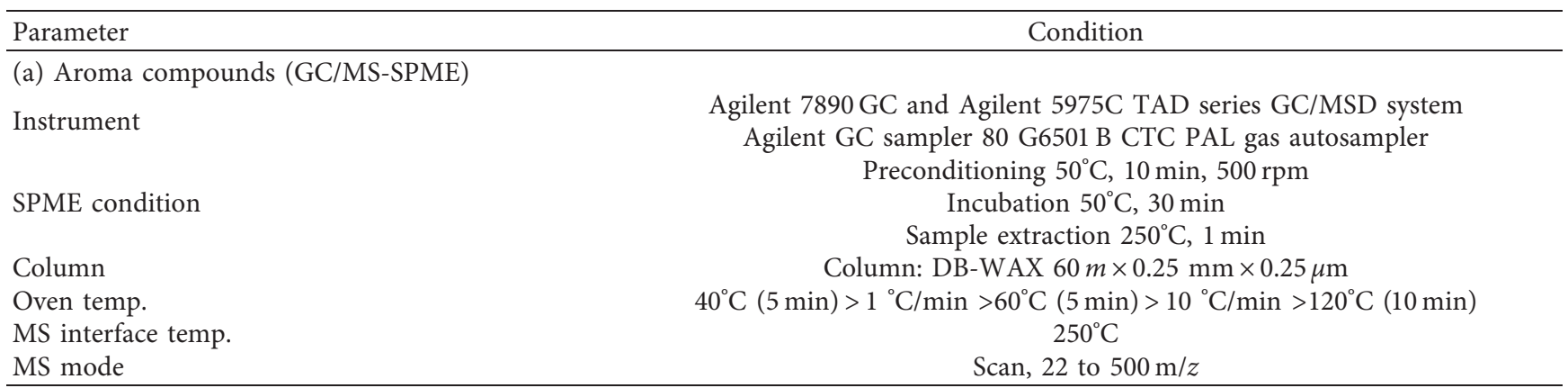

(b) Amino acid (HPLC-UVD).

Instrument

Agilent 1290 high-performance liquid chromatography-ultraviolet detector (HPLCUVD)

Solvent $\mathrm{a}=40 \mathrm{mM}$ sodium dihydrogen phosphate (NaH2PO4), $\mathrm{pH} 7.8$ buffer. Solvent $B=$ acetonitrile $(\mathrm{ACN}):$ Methanol $(\mathrm{MeOH})$ : Water $(45: 45: 10)$

\begin{tabular}{|c|c|c|}
\hline \multirow{9}{*}{ Mobile phase } & 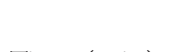 & ※ gradient \\
\hline & Time (min) & $\% \mathrm{~A}$ \\
\hline & 0 & 100 \\
\hline & 1 & 100 \\
\hline & 9.8 & 43 \\
\hline & 10 & 0 \\
\hline & 12 & 0 \\
\hline & 12.5 & 100 \\
\hline & 14 & 100 \\
\hline Flow rate & & $0.25 \mathrm{~mL} / \mathrm{min}$ \\
\hline Injection volume & & $1 \mu \mathrm{L}$ \\
\hline Column & & Agilent Zorbax Eclipse AAA $(4.6 \mathrm{~m} \times 75 \mathrm{~mm} \times 3.5 \mu \mathrm{m})$ \\
\hline Column temperature & & $40^{\circ} \mathrm{C}$ \\
\hline Detector wavelength & & $338 \mathrm{~nm}$ \\
\hline Run time & & $14 \mathrm{~min}$ \\
\hline
\end{tabular}

(c) Nucleotides (HPLC-UVD)

Instrument

Agilent 1290 high-performance liquid chromatography-ultraviolet detector (HPLCUVD)

Solvent $\mathrm{a}=$ potassium dihydrogen phosphate $(\mathrm{KH} 2 \mathrm{PO} 4) 10 \mathrm{mM}$ in water $(\mathrm{pH} 5.6$ adjusted with $5 \mathrm{~N}$ potassium hydroxide $(\mathrm{KOH})$ solution) Solvent $B=$ methanol $100 \%$

Mobile phase

Time $(\mathrm{min})$
0
12.5
15
17.5
20

$※$ gradient $\% \mathrm{~A}$

p

$\begin{array}{cc}\% \mathrm{~A} & \% \mathrm{~B} \\ 100 & 0 \\ 90 & 10 \\ 80 & 20 \\ 100 & 0 \\ 100 & 0 \\ 0.6 \mathrm{~mL} / \mathrm{min} & \\ 10 \mu \mathrm{L} & \\ \text { Waters SunFire } \mathrm{C} 18(4.6 \mathrm{~mm} \times 250 \mathrm{~mm} \times 5.0 \mu \mathrm{m}) & \\ 40^{\circ} \mathrm{C} & \\ 254 \mathrm{~nm} & \\ 20 \mathrm{~min} & \end{array}$

Flow rate

Injection volume

Column

Column temperature

Detector wavelength $20 \mathrm{~min}$

GC/MS: gas chromatography-mass spectrometry; SPME: solid-phase microextraction, HPLC-UVD: high-performance liquid chromatography-ultraviolet detector, HPLC-UVD: high-performance liquid chromatography-ultraviolet detector. 
TABLE 2: Fragrance component composition by gas chromatography-mass spectrometry solid-phase microextraction analysis (GC-MSSPME) (component name, CAS number, detection state, peak area).

\begin{tabular}{|c|c|c|c|c|c|c|c|c|c|}
\hline \multirow{2}{*}{ Library compound name } & \multirow{2}{*}{ CAS\# } & \multicolumn{2}{|c|}{ Green onion extract } & \multicolumn{2}{|c|}{ Garlic extract } & \multicolumn{2}{|c|}{ Beef bone extract } & \multicolumn{2}{|c|}{ Chicken bone extract } \\
\hline & & Nonroasting & Roasting & Nonroasting & Roasting & Nonroasting & Roasting & Nonroasting & Roasting \\
\hline Hexanol & $\begin{array}{l}000111- \\
27-3\end{array}$ & - & - & - & - & - & 10631 & - & 20067 \\
\hline Heptanol & $\begin{array}{c}000111- \\
70-6\end{array}$ & - & - & - & 25801 & 56101 & 90639 & 23015 & 125555 \\
\hline Butanal & $\begin{array}{l}00059- \\
86-3\end{array}$ & - & 16159 & - & - & - & - & - & - \\
\hline Hexanal & $\begin{array}{l}000066- \\
25-1\end{array}$ & - & 32673 & - & - & 198326 & 298789 & - & 1579467 \\
\hline Heptanal & $\begin{array}{l}000111- \\
71-7\end{array}$ & - & - & - & - & 139990 & 196425 & - & 183424 \\
\hline Octanal & $\begin{array}{c}000124- \\
13-0\end{array}$ & 11813 & - & - & - & 88891 & 157049 & - & 186542 \\
\hline Nonenal & $\begin{array}{c}002277- \\
19-2\end{array}$ & - & - & - & - & - & - & - & 110701 \\
\hline Heptane & $\begin{array}{l}000142- \\
82-5\end{array}$ & - & - & - & - & - & - & - & - \\
\hline Octane & $\begin{array}{c}000111- \\
65-9\end{array}$ & - & - & - & - & - & 51285 & 93944 & 108699 \\
\hline Decane & $\begin{array}{c}000124- \\
18-5\end{array}$ & - & - & - & - & 270527 & 190413 & 531869 & 354858 \\
\hline Dodecane & $\begin{array}{c}000112- \\
40-3\end{array}$ & - & - & - & - & 154636 & 109759 & 320471 & 196023 \\
\hline $\begin{array}{l}\text { Methane, thiobis-(methyl } \\
\text { sulphide) }\end{array}$ & $\begin{array}{c}000075- \\
18-3\end{array}$ & 40465 & 32749 & - & - & - & - & - & - \\
\hline $\begin{array}{l}\text { cis-Propenyl methyl } \\
\text { disulphide (methyl allyl } \\
\text { disulphide) }\end{array}$ & $\begin{array}{l}005905- \\
47-5\end{array}$ & - & 27017 & - & - & - & - & - & - \\
\hline Dimethyl trisulphide & $\begin{array}{c}003658- \\
80-8\end{array}$ & 18184 & 8160 & - & 25851 & - & - & - & - \\
\hline Disulphide, di-2-propenyl & $\begin{array}{c}002179- \\
57-9\end{array}$ & - & - & 357458 & 396027 & - & - & - & - \\
\hline $\begin{array}{l}\text { Disulphide, methyl 2- } \\
\text { propenyl }\end{array}$ & $\begin{array}{c}002179- \\
58-0\end{array}$ & - & - & 96447 & 153590 & - & - & - & - \\
\hline
\end{tabular}

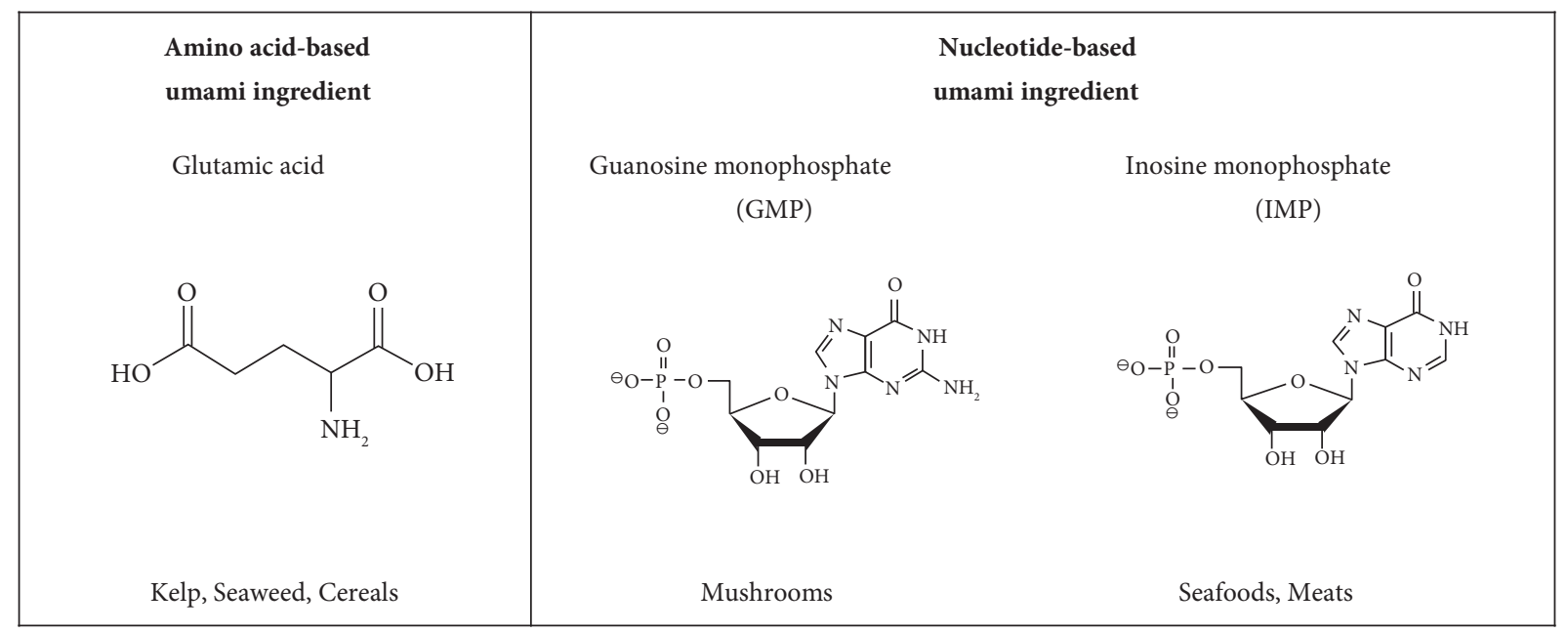

Figure 2: Types of umami ingredients-representative source and chemical structure. 
TABLE 3: Comparison of amino acid composition of roasted and nonroasted raw materials.

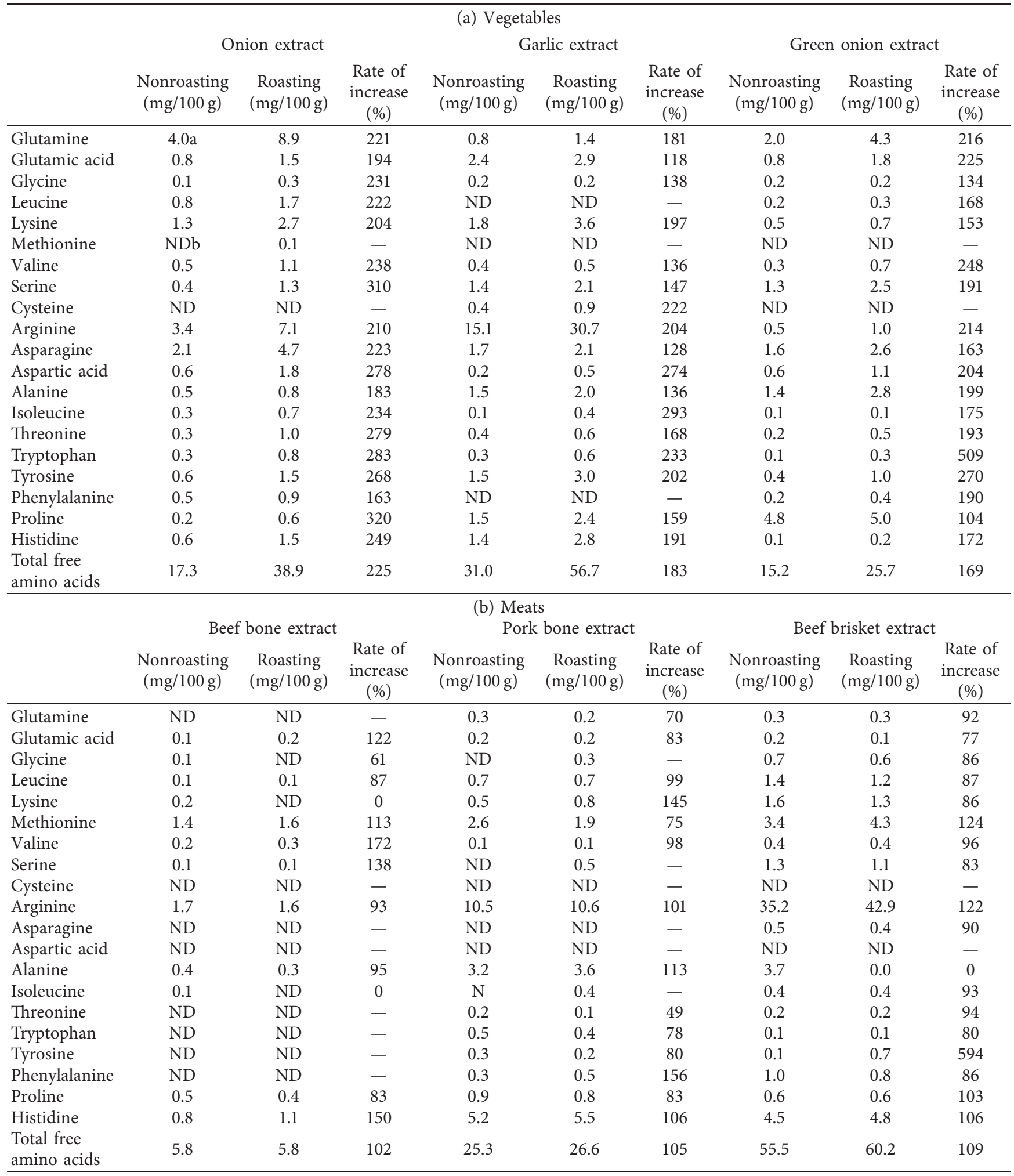


TABLE 3: Continued.

(a) Vegetables

Onion extract

\begin{tabular}{|c|c|c|c|c|c|c|c|c|c|}
\hline & \multicolumn{3}{|c|}{ Onion extract } & \multicolumn{3}{|c|}{ Garlic extract } & \multicolumn{3}{|c|}{ Green onion extract } \\
\hline & $\begin{array}{l}\text { Nonroasting } \\
(\mathrm{mg} / 100 \mathrm{~g})\end{array}$ & $\begin{array}{l}\text { Roasting } \\
(\mathrm{mg} / 100 \mathrm{~g})\end{array}$ & $\begin{array}{c}\text { Rate of } \\
\text { increase } \\
(\%)\end{array}$ & $\begin{array}{l}\text { Nonroasting } \\
(\mathrm{mg} / 100 \mathrm{~g})\end{array}$ & $\begin{array}{l}\text { Roasting } \\
(\mathrm{mg} / 100 \mathrm{~g})\end{array}$ & $\begin{array}{c}\text { Rate of } \\
\text { increase } \\
(\%)\end{array}$ & $\begin{array}{l}\text { Nonroasting } \\
(\mathrm{mg} / 100 \mathrm{~g})\end{array}$ & $\begin{array}{l}\text { Roasting } \\
(\mathrm{mg} / 100 \mathrm{~g})\end{array}$ & $\begin{array}{c}\text { Rate of } \\
\text { increase } \\
(\%)\end{array}$ \\
\hline & \multicolumn{3}{|c|}{ Beef tendon extract } & \multicolumn{3}{|c|}{ Chicken feet extract } & \multicolumn{3}{|c|}{ Chicken breast extract } \\
\hline & $\begin{array}{c}\text { Nonroasting } \\
(\mathrm{mg} / 100 \mathrm{~g})\end{array}$ & $\begin{array}{l}\text { Roasting } \\
(\mathrm{mg} / 100 \mathrm{~g})\end{array}$ & $\begin{array}{c}\text { Rate of } \\
\text { increase } \\
(\%)\end{array}$ & $\begin{array}{l}\text { Nonroasting } \\
(\mathrm{mg} / 100 \mathrm{~g})\end{array}$ & $\begin{array}{l}\text { Roasting } \\
(\mathrm{mg} / 100 \mathrm{~g})\end{array}$ & $\begin{array}{c}\text { Rate of } \\
\text { increase } \\
(\%)\end{array}$ & $\begin{array}{l}\text { Nonroasting } \\
(\mathrm{mg} / 100 \mathrm{~g})\end{array}$ & $\begin{array}{l}\text { Roasting } \\
(\mathrm{mg} / 100 \mathrm{~g})\end{array}$ & $\begin{array}{c}\text { Rate of } \\
\text { increase } \\
(\%)\end{array}$ \\
\hline Glutamine & 0.1 & 0.1 & 112 & 0.3 & 0.3 & 98 & 1.0 & 1.1 & 109 \\
\hline Glutamic acid & 0.2 & 0.2 & 87 & 0.2 & 0.2 & 115 & 0.1 & 0.2 & 163 \\
\hline Glycine & 0.2 & 0.2 & 118 & 0.6 & ND & 0 & 1.1 & 1.3 & 115 \\
\hline Leucine & 0.2 & 0.3 & 189 & 0.8 & 1.0 & 129 & 1.6 & 2.4 & 152 \\
\hline Lysine & 0.3 & 0.4 & 109 & 2.3 & 0.2 & 9 & 3.0 & 3.8 & 126 \\
\hline Methionine & 2.5 & 4.4 & 178 & 2.6 & 4.3 & 168 & 4.5 & 5.0 & 112 \\
\hline Valine & 0.5 & 0.6 & 129 & 0.3 & 0.3 & 110 & 0.6 & 0.8 & 142 \\
\hline Serine & 0.2 & 0.4 & 184 & 0.3 & 0.0 & 0 & 2.1 & 3.6 & 173 \\
\hline Cysteine & ND & ND & - & 0.1 & 0.0 & 0 & 0.0 & 0.0 & - \\
\hline Arginine & 5.7 & 7.0 & 123 & 6.8 & 6.0 & 88 & 41.6 & 54.3 & 130 \\
\hline Asparagine & $\mathrm{ND}$ & 0.1 & - & $\mathrm{ND}$ & ND & - & 0.5 & 0.8 & 155 \\
\hline Aspartic acid & ND & ND & - & ND & ND & - & ND & ND & - \\
\hline Alanine & 1.5 & 2.6 & 177 & 3.6 & 4.1 & 112 & 14.2 & 14.4 & 101 \\
\hline Isoleucine & 0.1 & 0.2 & 232 & 0.5 & 0.6 & 115 & 0.3 & 0.2 & 78 \\
\hline Threonine & ND & 0.1 & - & 0.1 & 0.2 & 224 & 0.2 & 0.2 & 148 \\
\hline Tryptophan & ND & 0.4 & - & 0.2 & ND & 14 & 0.2 & 0.2 & 119 \\
\hline Tyrosine & ND & 0.2 & - & 0.6 & 0.8 & 134 & 1.1 & 0.1 & 9 \\
\hline Phenylalanine & 0.2 & 0.2 & 148 & 0.4 & 0.7 & 183 & 1.1 & 1.8 & 161 \\
\hline Proline & 0.8 & 0.4 & 50 & 1.8 & 1.4 & 76 & 1.6 & 1.4 & 87 \\
\hline Histidine & 2.2 & 2.8 & 126 & 7.6 & 8.8 & 117 & 7.9 & 10.4 & 132 \\
\hline $\begin{array}{l}\text { Total free } \\
\text { amino acids }\end{array}$ & 14.6 & 20.6 & 141 & 29.1 & 29.0 & 100 & 82.8 & 102.2 & 123 \\
\hline
\end{tabular}

${ }^{a}$ The values are mean \pm S.D. of three replications. ${ }^{b} \mathrm{ND}:$ Not detected or low intensity under limit of detection.

study, research on temperature conditions could be an important future task.

As a result of the analysis of six kinds of livestock products, it was found that the increase was approximately two- to three-fold in beef brisket and chicken. It was estimated that the level of influence on fulfilment was negligible. Livestock products that showed the greatest effect with roasting were pork bone extract and beef tendon extract in this order, and other livestock products showed an effect of less than three times of the increase rate.

Consequently, although the absolute content level was low, it was confirmed that the extraction efficiency of nucleotidebased components of livestock products during the roasting treatment was higher compared to when only water extraction was performed. The nucleotide composition data are shown in Table 4.

\subsection{Changes in Aroma and Taste Components in Mixed Sauces} (Finished Products) with Convection Heated Roasting. To examine the levels of differences in the contents of aroma and taste components in mixed sauces (finished product) depending on whether the raw material was roasted, the finished product was compared and inspected by adding the broth base and seasoning. Raw materials were subjected to a convection oven process, and seasoning ingredients were used in the finished product. The separation of key-based broth and mixed sauce was designed so that it could be applied to various products in the future. In particular, in the case of the key-based broth, it was necessary to separately analyse it because it was prepared by targeting the richness of the aroma component rather than the absolute amount of the taste component.

3.2.1. Changes in Mixed Sauce's Aroma Composition. As described above, the dozens of aromas were observed in each sample. After selecting significant peaks by considering peak sensitivity of each compound among the massive data, overlapping compounds were sorted, and remarkable differences and commonalities could be identified. Regardless of roasting, the compounds that were commonly increased were pentadecane (waxy fat flavour), benzaldehyde (almond flavour), and 2-octylfuran (chocolate flavour). The compounds that were commonly decreased were 2-acetylthiazole (coriander leaf flavour), methylpyrazine (mould, ammonia flavour), and 3methyl-butanal (dry fruit flavour, putrefactive flavour).

In the case of roasting raw material, 1-propene (garlic flavour), eucalyptol (mint, refreshing flavour), and octanal (savoury fatty flavour) were observed as unique ingredients during roasting and are estimated to be positive flavour ingredients. The nonroasting raw material ingredients were 2, 5-dimethylpyrazine (bad smell stinging the nose), 


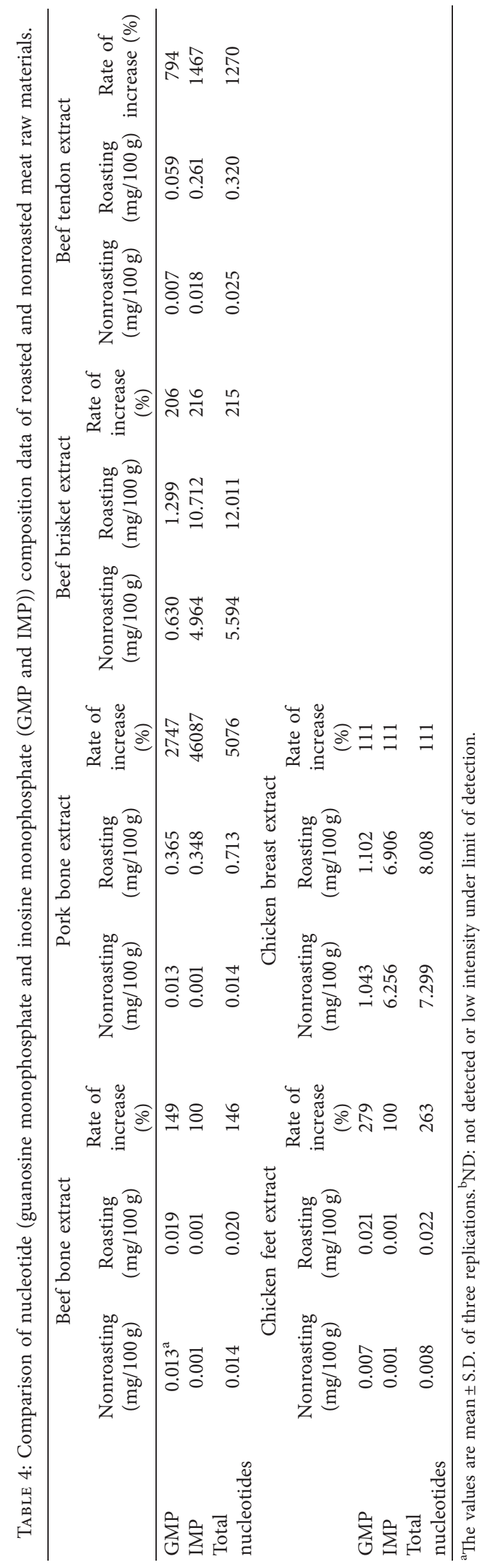




\section{4 compounds 18 compounds 20 compounds}

Roasting mixed sauce

Non-roasting mixed sauce

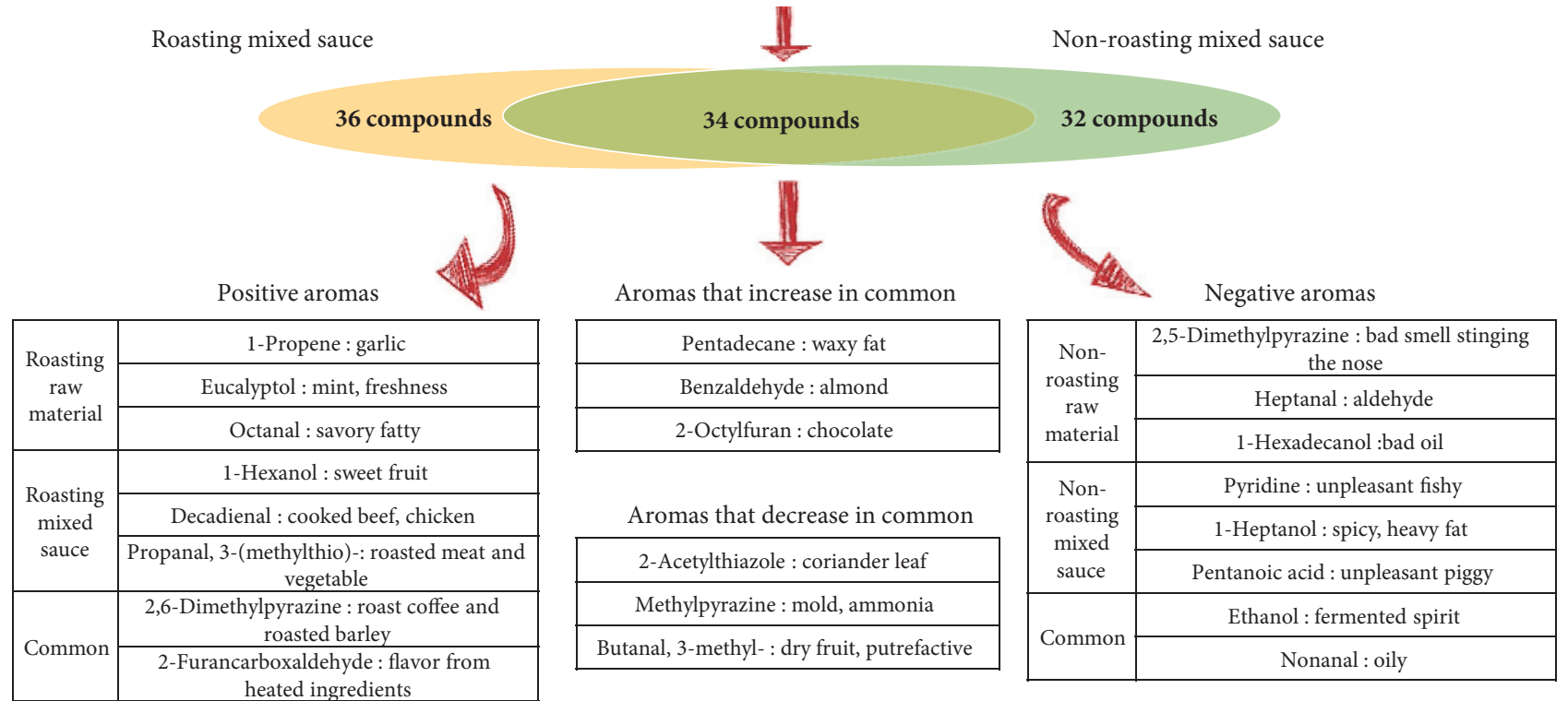

Figure 3: Composition of aroma components of raw material and mixed sauce according to roasting or nonroasting condition.

TABLE 5: Comparison of amino acid and nucleotide (guanosine monophosphate and inosine monophosphate (GMP, IMP)) composition of roasted and nonroasted mixed sauce products.

\begin{tabular}{|c|c|c|c|c|c|c|c|c|c|c|}
\hline & \multicolumn{5}{|c|}{ Key-based samples } & \multicolumn{5}{|c|}{ Finished products } \\
\hline & \multicolumn{2}{|c|}{$\begin{array}{l}\text { Nonroasting } \\
(\mathrm{mg} / 100 \mathrm{~g})\end{array}$} & \multicolumn{2}{|c|}{$\begin{array}{l}\text { Roasting } \\
(\mathrm{mg} / 100 \mathrm{~g})\end{array}$} & \multirow[t]{2}{*}{ Rate of increase (\%) } & \multicolumn{2}{|c|}{$\begin{array}{l}\text { Nonroasting } \\
(\mathrm{mg} / 100 \mathrm{~g})\end{array}$} & \multicolumn{2}{|c|}{$\begin{array}{l}\text { Roasting } \\
(\mathrm{mg} / 100 \mathrm{~g})\end{array}$} & \multirow[t]{2}{*}{ Rate of increase (\%) } \\
\hline & Average & SD & Average & $\mathrm{SD}$ & & Average & SD & Average & $\mathrm{SD}$ & \\
\hline Glutamine & $0.2 \mathrm{a}$ & 0.4 & $\mathrm{NDb}$ & 0.0 & -100.0 & 0.9 & 0.9 & 1.3 & 1.3 & 43.6 \\
\hline Glutamic acid & 5.2 & 1.2 & 7.1 & 0.7 & 38.1 & 146.2 & 2.4 & 159.3 & 2.0 & 8.9 \\
\hline Glycine & 3.3 & 0.1 & 3.1 & 0.4 & -8.2 & 28.6 & 0.5 & 30.8 & 0.4 & 7.8 \\
\hline Leucine & 0.1 & 0.2 & 0.9 & 0.1 & 855.2 & 82.4 & 1.1 & 89.0 & 1.6 & 8.0 \\
\hline Lysine & 2.1 & 0.3 & 3.0 & 0.4 & 43.4 & 54.1 & 1.9 & 57.9 & 2.5 & 7.1 \\
\hline Methionine & ND & - & ND & - & - & 15.4 & 0.2 & 16.9 & 0.2 & 9.5 \\
\hline Valine & 1.8 & 0.6 & 2.7 & 1.0 & 51.1 & 53.9 & 0.7 & 58.9 & 0.9 & 9.2 \\
\hline Serine & ND & - & 1.6 & 0.3 & - & 50.0 & 0.6 & 53.2 & 1.2 & 6.2 \\
\hline Cysteine & 0.3 & 0.5 & 0.3 & 0.3 & -11.9 & 1.3 & 1.7 & 0.3 & 0.1 & -76.2 \\
\hline Arginine & 10.1 & 2.0 & 7.7 & 1.6 & -23.8 & 51.3 & 0.5 & 54.3 & 1.2 & 5.7 \\
\hline Asparagine & 5.9 & 0.3 & 5.2 & 0.2 & -12.0 & 27.8 & 0.4 & 28.7 & 0.3 & 3.2 \\
\hline Aspartic acid & ND & - & 1.7 & 1.2 & - & 50.6 & 1.0 & 55.3 & 0.3 & 9.3 \\
\hline Alanine & 13.0 & 0.3 & 14.9 & 1.1 & 15.2 & 119.0 & 1.7 & 128.2 & 2.0 & 7.7 \\
\hline Isoleucine & ND & - & ND & - & - & 39.8 & 0.7 & 43.5 & 0.9 & 9.4 \\
\hline Threonine & 0.3 & 0.4 & 1.2 & 0.6 & 261.3 & 34.6 & 0.5 & 37.7 & 0.5 & 9.0 \\
\hline Tryptophan & 4.1 & 0.3 & 4.0 & 0.4 & -2.1 & 15.8 & 0.4 & 7.6 & 7.8 & -51.7 \\
\hline Tyrosine & ND & - & 0.5 & 0.5 & - & 32.7 & 1.7 & 36.0 & 0.6 & 10.2 \\
\hline Phenylalanine & 0.1 & 0.2 & 0.6 & 0.5 & 477.0 & 48.5 & 0.7 & 52.8 & 1.2 & 8.7 \\
\hline Proline & 4.0 & 0.3 & 7.6 & 0.0 & 89.4 & 57.4 & 6.7 & 50.4 & 10.1 & -12.3 \\
\hline Histidine & $\mathrm{ND}$ & - & 0.6 & 1.0 & - & 10.0 & 1.0 & 11.7 & 0.3 & 17.5 \\
\hline Total free amino acids & 50.5 & 0.4 & 62.6 & 3.0 & 24.1 & 920.4 & 11.3 & 973.6 & 7.3 & 5.8 \\
\hline GMP & 10.6 & 0.5 & 11.2 & 0.5 & 5.9 & 1171.6 & 17.1 & 1177.9 & 6.4 & 0.5 \\
\hline IMP & 34.0 & 1.7 & 27.3 & 0.7 & -19.7 & 1643.6 & 23.7 & 1651.0 & 8.7 & 0.5 \\
\hline GMP + IMP & 44.5 & 2.2 & 38.5 & 1.2 & -13.8 & 2815.1 & 40.8 & 2828.9 & 15.1 & 1.0 \\
\hline
\end{tabular}

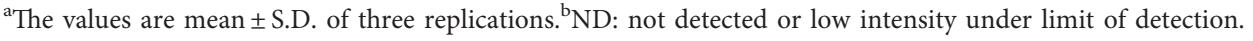


Key-based sample (raw material extracts)

\begin{tabular}{|c|c|c|c|c|}
\hline \multicolumn{2}{|c|}{ Characteristics } & Non-roasting & Roasting & $\begin{array}{c}\text { Rate of increase } \\
\text { (\%) }\end{array}$ \\
\hline \multirow{2}{*}{ Taste } & Total free amino acids & $50.5 \mathrm{mg} / 100 \mathrm{~g}$ & $62.6 \mathrm{mg} / 100 \mathrm{~g}$ & $24.1 \%$ \\
\hline & Glutamic acid & $5.2 \mathrm{mg} / 100 \mathrm{~g}$ & $7.1 \mathrm{mg} / 100 \mathrm{~g}$ & $38.1 \%$ \\
\hline \multirow{4}{*}{ Aroma } & & 2,5-Dimethylpyrazine : stinks & 1-Propene : garlic & \\
\hline & Inherence & $\begin{array}{l}\text { Heptanal : aldehyde } \\
\text { 1-Hexadecanol : bad oil }\end{array}$ & $\begin{array}{l}\text { Eucalyptol : mint, refreshing } \\
\text { Octanal : savoryfat }\end{array}$ & - \\
\hline & $\begin{array}{l}\text { Common } \\
\text { (increase when } \\
\text { roasting) }\end{array}$ & - & $\begin{array}{l}\text { Pentadecane : waxy fat } \\
\text { Benzaldehyde : typical almond } \\
\text { 2-Octylfuran : chocolate }\end{array}$ & - \\
\hline & $\begin{array}{l}\text { Common } \\
\text { (decrease when } \\
\text { roasting) }\end{array}$ & $\begin{array}{c}\text { 2-Acetylthiazole : coriander leaf } \\
\text { Methylpyrazine : mold, ammonia } \\
\text { Butanal, 3-methyl-: dry fruit, } \\
\text { putrefactive }\end{array}$ & - & - \\
\hline
\end{tabular}

Finished product (key-based sample + seasoning ingredients)

\begin{tabular}{|c|c|c|c|c|}
\hline \multicolumn{2}{|c|}{ Characteristics } & Non-roasting & Roasting & $\begin{array}{c}\text { Rate of increase } \\
(\%)\end{array}$ \\
\hline \multirow{2}{*}{ Taste } & Total free amino acids & $920.4 \mathrm{mg} / 100 \mathrm{~g}$ & $973.6 \mathrm{mg} / 100 \mathrm{~g}$ & $5.8 \%$ \\
\hline & Glutamic acid & $146.2 \mathrm{mg} / 100 \mathrm{~g}$ & $159.3 \mathrm{mg} / 100 \mathrm{~g}$ & $8.9 \%$ \\
\hline \multirow{3}{*}{ Aroma } & Inherence & $\begin{array}{c}\text { Pyridine : unpleasant fishy } \\
\text { 1-Heptanol : Spicy, heavy fat } \\
\text { Pentanoic acid : unpleasant piggy }\end{array}$ & $\begin{array}{l}\text { 1-Hexanol : sweet fruit } \\
\text { Decadienal : cooking flavors } \\
\text { evaluated as positive aromas } \\
\text { such as beef and chicken } \\
\text { Propanal, 3-(methylthio)- : roast } \\
\text { meat and vegetables }\end{array}$ & - \\
\hline & $\begin{array}{l}\text { Common } \\
\text { (increase when } \\
\text { roasting) }\end{array}$ & - & $\begin{array}{l}\text { Pentadecane : waxy fat } \\
\text { Benzaldehyde : typical almond } \\
\text { 2-Octylfuran :chocolate }\end{array}$ & - \\
\hline & $\begin{array}{l}\text { Common } \\
\text { (decrease when } \\
\text { roasting) }\end{array}$ & $\begin{array}{l}\text { 2-Acetylthiazole : coriander leaf } \\
\text { Methylpyrazine : mold, ammonia } \\
\text { Butanal, 3-methyl- : dry fruit, } \\
\text { putrefactive }\end{array}$ & - & - \\
\hline
\end{tabular}

FIGURE 4: Summarised positive effects of convection heated roasting extraction in sauce products.

heptanal (aldehyde flavour), and 1-hexadecanol (bad oil flavour), which were estimated to be negative flavour ingredients.

In the case of the mixed finished product sauce, 1hexanol (sweet fruit flavour), decadienal (cooked beef, chicken flavour), and 3-(methylthio)-propanal (roasted meat and vegetable flavour) were observed as unique ingredients during roasting. They are positive fragrance ingredients. Pyridine (unpleasant fishy flavour), 1-heptanol (spicy flavour, heavy fat flavour), and pentanoic acid (unpleasant piggy flavour) were observed and were estimated to be negative flavour ingredients.

On the one hand, in common aromas with roasting between the raw material and the finished product sauce, 2,6dimethylpyrazine (roasted coffee and roasted barley flavour) and 2-furancarboxaldehyde (flavour from heated ingredients) were observed as unique ingredients, and they are estimated to be positive flavour ingredients. On the other hand, without roasting, ethanol (fermented spirit flavour) and nonanal (oily flavour) were observed as unique ingredients, and they were estimated to be negative fragrance ingredients. All aromas for the raw materials and products are schematised in Figure 3.
3.2.2. Changes in the Umami Component of the Mixed Sauces. In the key-based samples (just a mix of raw materials), the total AA content increased by $24.1 \%$ during convection heated roasting, and glutamic acid, the umami component among AA, increased by $38.1 \%$, indicating a high increase rate compared to the total AA. The key-based nucleotide-based flavour ingredients (GMP, IMP) increased by $5.9 \%$ in GMP, but decreased by $19.7 \%$ in IMP, indicating that the total amount of nucleotide-based ingredients decreased by $13.8 \%$.

In the finished product (mixed raw materials and seasoning ingredients), the total AA content increased by $5.8 \%$ during roasting, and glutamic acid content increased by $8.9 \%$. In contrast, the nucleotide-based taste ingredients in the finished product were not significantly different as it increased by only $1 \%$.

Overall, AAs, including glutamic acid, were significantly increased by roasting and had an effect as an umami ingredient; however, in the case of nucleotide-based flavour ingredients, roasting had no significant effect. The taste composition of mixed sauce data is shown in Table 5.s 


\section{Conclusions}

Vegetables, meat, and mixed extracted sauces were subjected to roasting in a convection oven, and the focus was on observing the changes in aroma and taste components (particularly umami). In the case of key-based samples (raw material extracts), the total AA and glutamic acid contents increased to 24.1-38.1\% owing to convection heated roasting. Aroma compounds that were increased included 1-propene (garlic), eucalyptol (mint, refreshing flavour), octanal (savoury fat flavour), pentadecane (waxy fat flavour), benzaldehyde (typical almond flavour), and 2-octylfuran (chocolate flavour). These were scents that were evaluated as positive aromas. In the case of the finished product (key-based sample + seasoning ingredients), the total AA and glutamic acid contents slightly increased to $5.8-8.9 \%$. By contrast, positive aromas were newly created or increased after roasting as follows: 1-hexanol (sweet fruit flavour), decadienal (cooking flavours evaluated as positive aromas such as beef and chicken), propanal, 3(methylthio) (roast meat and vegetables), pentadecane (waxy fat flavour), benzaldehyde (typical almond flavour), and 2Octylfuran (chocolate flavour). In the case of nucleotide-based taste components, there was no significant increase in the content. The positive effects of the convection heated roasting extraction are summarised in Figure 4.

$\mathrm{n}$ conclusion, it was demonstrated that the application of novel convection heated roasting techniques for raw vegetable and meat materials, whether alone or in combination with traditional hot water extraction, had a positive effect for good aroma and increasing taste of umami. Through the extraction conditions and techniques described in this study, it will be possible to improve the quality of finished products related to the production of sauces. It will also be helpful for basic research activities that can improve the flavour and taste of raw materials. In this study, we measured an increase in the content of useful components in raw materials and final products or positive changes in fragrance components. The present findings contribute immensely to the food industry as the enhancement of taste and aroma could help with the production of more palatable foods as desired by food consumers, thereby increasing the sales of nutritious foods that otherwise consumers may not buy. However, there was a limitation in this study, because quantitative measurement of the fragrance component was not performed and it was merely observing a positive fragrance. In future scientific studies, sensory evaluations need to be performed using electronic nose and electronic tongue devices combined with the traditional sensory evaluation. Further research on roasting techniques is also required.

\section{Data Availability}

The data used to support the findings of this study are available from the corresponding author upon request.

\section{Conflicts of Interest}

The authors declare that there are no conflicts of interest regarding the publication of this article.

\section{Acknowledgments}

The authors would like to thank Editage (http://www. editage.co.kr) for English language editing.

\section{Supplementary Materials}

Roasting data for total aroma analysis. Supplementary Materials (Supplementary Materials)

\section{References}

[1] J. W. Shim, "Molecular biological evaluation of taste," Food Industry and Nutrition, vol. 21, no. 1, pp. 1-4, 2016.

[2] M. R. Ryu, "Gustation targeting sodium and sugar reduction," Food Science and Industry, vol. 50, no. 4, pp. 12-23, 2017.

[3] J. K. Kim, "Flavors of processed food in heating," Food Industry and Nutrition, vol. 6, no. 2, pp. 20-26, 2001.

[4] K. Ikeda, "A production method of seasoning mainly consists of salt of L-glutamic acid," Japanese Patent 14805, 1908.

[5] K. Ikeda, "On the taste of the salt of glutamic acid," International Congress of Pure and Applied Chemistry, vol. 18, Article ID 147, 1912.

[6] S. Kodama, "On a procedure for separating Inosinic acid," Journal of the Chemical Society of Tokyo, vol. 34, Article ID 751, 1913.

[7] A. Kuninaka, "Studies on taste of ribonucleic acid derivatives," Journal of the Agricultural Chemical Society of Japan, vol. 34, pp. 487-492, 1960.

[8] A. Kuninaka, The Nucleotides, a Rationale of Research on Flavor Potentiation, Symposium on Flavor Potentiation, pp. 4-9, Arthur D. Little, Cambridge, MA, USA, 1964.

[9] K. Sakaguchi, M. Kibi, and A. Kuninaka, "Japanese patent application SN 11586 and US," Patent Application, vol. 541, 1958 SN 756.

[10] K. Ninomiya, "Natural occurrence," Food Review, vol. 14, no. 2\&3, pp. 177-211, 1998.

[11] S. Yamaguchi and K. Ninomiya, Umami and food palatability, American Society for Nutritional Sciences, Rockville, MD, USA, 2000.

[12] D. S. Mottram, "Flavour formation in meat and meat products: a review," Food Chemistry, vol. 62, no. 4, pp. 415-424, 1998.

[13] A. Rawson, A. Patras, B. K. Tiwari, F. Noci, T. Koutchma, and N. Brunton, "Effect of thermal and non thermal processing technologies on the bioactive content of exotic fruits and their products: review of recent advances," Food Research International, vol. 44, no. 7, pp. 1875-1887, 2011.

[14] H. S. Chung, J. K. Kim, and K. S. Youn, "Effects of roasting temperature on phycochemical properties of job's tears (Coix lachryma jobi L var ma-yeun) powder and extracts," Korean Journal of Food Preservation, vol. 13, pp. 477-482, 2006.

[15] I. G. Hwang, K. S. Woo, and H. S. Jeong, "Biological activity and heat treatment processing of foods," Food Science and Industry, vol. 44, pp. 56-65, 2011.

[16] C. S. Suh and J. K. Chun, "Relationship among the roasting conditions, colors and extractionable solid content of roasted barley," Korean Journal of Food Science and Technology, vol. 13, pp. 334-339, 1981.

[17] C. Delgado-Andrade, I. Seiquer, A. Haro, R. Castellano, and M. P. Navarro, "Development of the Maillard reaction in foods cooked by different techniques. Intake of Maillard- 
derived compounds," Food Chemistry, vol. 122, no. 1, pp. 145-153, 2010.

[18] M. Hellwig and T. Henle, "Baking, ageing, diabetes: a short history of the maillard reaction," Angewandte Chemie International Edition, vol. 53, no. 39, pp. 10316-10329, 2014.

[19] M. Marcotte, "Heat and mass transfer during baking," Heat Transfer in Food Processing, vol. 8, pp. 239-265, 2008.

[20] M. J. Blikra, D. Skipnes, and A. H. Feyissa, "Model for heat and mass transport during cooking of cod loin in a convection oven," Food Control, vol. 102, pp. 29-37, 2019.

[21] W. Chumngoen, C.-F. Chen, and F.-J. Tan, "Effects of moist- and dry-heat cooking on the meat quality, microstructure and sensory characteristics of native chicken meat," Animal Science Journal, vol. 89, pp. 193-201, 2018.

[22] M. J. Lee, S. E. Kim, J. H. Kim, S. W. Lee, and D. M. Yeum, “A Study of coffee bean characteristics and coffee flavors in relation to roasting," Journal of the Korean Society of Food Science and Nutrition, vol. 42, no. 2, pp. 255-261, 2013.

[23] F. Mayer, M. Czerny, and W. Grosch, "Sensory study of the character impact aroma compounds of a coffee beverage," European Food Research and Technology, vol. 211, no. 4, pp. 272-276, 2000.

[24] C. Sanz, D. Ansorena, J. Bello, and C. Cid, "Optimizing headspace temperature and time sampling for identification of volatile compounds in ground roasted Arabica coffee," Journal of Agricultural and Food Chemistry, vol. 49, no. 3, pp. 1364-1369, 2001.

[25] E. Nebesny, G. Budryn, J. Kula, and T. Majda, "The effect of roasting method on headspace composition of robusta coffee bean aroma," European Food Research and Technology, vol. 225, no. 1, pp. 9-19, 2007.

[26] P. S. Wang and Y. Sacurai, "Studies on flavor components of roasted barley, I The production of flavor substances," The Japanese Society for Food Science and Technology, vol. 15, pp. 22-26, 1968.

[27] W.-Y. Joung, S.-J. Kim, B.-G. Kim, B.-S. Hurh, and H.-H. Baek, "Effects of barley roasting methods on the aroma characteristics of boricha," Korean Journal of Food Science and Technology, vol. 50, no. 5, pp. 464-473, 2018.

[28] Y. Kim, Y. C. Lee, and K. O. Kim, "Optimum roasting and extraction conditions and flavor characteristics of roasted malt extract," Cereal Chemistry Journal, vol. 75, no. 3, pp. 282-288, 1998.

[29] S.-M. Jeong, S.-Y. Kim, D.-R. Kim, K. C. Nam, D. U. Ahm, and S. C. Lee, "Effect of seed roasting conditions on the antioxidant activity of defatted sesame meal extracts," Journal of Food Science, vol. 69, no. 5, pp. 377-381, 2004.

[30] Y.-B. Song, K.-S. Lee, M.-S. Lee, and A.-J. Kim, "Bioactivitiy changes in mung beans according to the roasting time," The Korean Journal of Food and Nutrition, vol. 26, no. 3, pp. 502-507, 2013.

[31] K.-H. Lee, A.-J. Kim, and M.-J. Kim, "Optimization of roasting condition to improve quality of freeze-dried silkworms using RSM," Asian Journal of Beauty and Cosmetology, vol. 18, no. 1, pp. 95-106, 2020.

[32] H. C. Ko, M. G. Jang, J. M. Oh et al., "Changes in chemical composition and antioxidant activity of dried Citrus unshiu peel after roasting," Lebensmittel-Wissenschaft \& Technologie, vol. 131, Article ID 109612, 2020.

[33] M. Park and K.-G. Lee, "Effect of roasting temperature and time on volatile compounds, total polyphenols, total flavonoids, and lignan of omija (Schisandra chinensis Baillon) fruit extract," Food Chemistry, vol. 338, Article ID 127836, 2021.
[34] Y. Sun, F. Lv, J. Tian, X. Q. Ye, J. Chen, and P. Sun, "Domestic cooking methods affect nutrient, phytochemicals, and flavor content in mushroom soup," Food Sciences and Nutrition, vol. 7, pp. 1969-1975, 2018.

[35] G.-H. An, J.-G. Han, and J.-H. Cho, "Changes in biological activities and nutritional contents of edible mushrooms following roasting treatment," Journal of Mushrooms, vol. 18, no. 1, pp. 63-71, 2020.

[36] G.-H. An, J.-G. Han, O.-T. Kim, and J.-H. Cho, "Changes of biological activities and nutrition contents by different extraction conditions in the mixtures of roasted edible mushrooms and grain additives for the development of mushroom tea," Journal of Mushrooms, vol. 18, no. 4, pp. 344-356, 2020.

[37] K.-H. Jeon, K.-H. Kwon, E.-M. Kim, Y.-B. Kim, D.-I. Sohn, and J.-Y. Choi, "Effect of cooking methods with various heating apparatus on the quality characteristics of beef," The Korean Journal of Culinary Research, vol. 19, no. 5, pp. 196205, 2013.

[38] K.-H. Jeon, K.-H. Kwon, E.-M. Kim, Y.-B. Kim, D.-I. Sohn, and J.-Y. Choi, "Effect of cooking methods with various heating apparatus on the quality characteristics of chicken," The Korean Journal of Culinary Research, vol. 20, no. 3, pp. 201-213, 2014.

[39] K.-H. Jeon, K.-H. Kwon, E.-M. Kim, Y.-B. Kim, and Y.-S. Choi, "Effect of cooking methods with various heating apparatus on the quality characteristics of pork," The Korean Journal of Culinary Research, vol. 21, no. 1, pp. 1-14, 2015.

[40] J. W. Henderson, R. D. Ricker, B. A. Bidlingmeyer, and C. Woodward, "Rapid, Accurate, Sensitive and Reproducible HPLC Analysis of Amino Acids," Agilent Technologies, Santa Clara, CA, USA, 2000.

[41] D. G. Brendon, E. I. Harvey, C. K. Maureen, K S. Nathan, M.-H. Merilyn, and D. Dawn, "5'-Mononucleotides in Infant Formula and Adult/pediatric Nutritional Formula by Liquid Chromatography," Journal of AOAC International, vol. 95, no. 3, pp. 599-602, 2012. 